\title{
In vivo biocompatibility of silicon dioxide nanofilm used as antimicrobial agent on acrylic surface
}

\author{
ROGÉRIO LACERDA-SANTOS, ANTONIA BÁRBARA L. LIMA, ELIZANDRA S. DA \\ PENHA, ANTONIELSON DOS SANTOS, FABÍOLA G. CARVALHO, MATHEUS M. \\ PITHON \& ANTÔNIO FLÁVIO M. DANTAS
}

\begin{abstract}
The focus of this study was to test the hypothesis that there would be no difference between the biocompatibility of silicon dioxide nanofilms used as antimicrobial agents. Sixty male Wistar rats were divided into 4 groups ( $n=15)$ : Group C (Control,Polyethylene), Group AR (Acrylic Resin), Group NP (Acrylic Resin coated with NPLiquid), Group BG (Acrylic Resin coated with Bacterlon). The animals were sacrificed with 7,15 and 30 days and tissues analyzed as regards the events of inflammatory infiltrate, edema, necrosis, granulation tissue, mutinucleated giant cells, fibroblasts and collagen. Kruskal-Wallis and Dunn tests was used $(P<0.05)$. Intense inflammatory infiltrate was shown mainly in Groups BG and AR, with significant difference from Control Group in the time interval of 7days $(P=0.004)$. Necrosis demonstrated significant difference between Group BG and Control Group $(P<0.05)$ in the time intervals of 7 days. For collagen fibers, there was significant difference between the Control Group and Groups AR and BG in the time interval of 7 days $(P=0.006)$, and between $B G$ and Control Groups in the time intervals of 15 days $(P=0.010)$. The hypothesis was rejected. Bacterlon demonstrated the lowest level, and NP-Liquid Glass the highest level of tissue compatibility, and best cell repair. The coating with NP-Liquid Glass was demonstrated to be highly promising for clinical use.
\end{abstract}

Key words: biomaterials, biocompatibility, dentistry, inflammation.

\section{INTRODUCTION}

The entire surface of the dental environment is subject to colonization by microorganisms (Mutters et al. 2014). In addition to this medium being subject to the proliferation of microorganisms, other surfaces could also serve as a medium for biofilm formation, such as acrylic resin dental prostheses and removable orthodontic appliances (Olsen \& Birkeland 1977). Studies (Compagnoni et al. 2014, Sesma et al. 2005) were conducted for the purpose of obtaining an inhibition of initial biofilm formation on these surfaces, either with antimicrobial agents incorporated into the methacrylate (Compagnoni et al. 2014), or by applying coatings or glazing substances (Sesma et al. 2005). However, some aspects of the results were not satisfactory, such as rapid depletion of the antimicrobial agent, or by the formation of cracks and or failures in the coatings (Compagnoni et al. 2014, Sesma et al. 2005).

The silicon dioxide based nanofilm $\left(\mathrm{SiO}_{2}\right)$ has been used as a bioprotective substance for surfaces susceptible to colonization by 
microorganisms, by means of an invisible $<250 \mathrm{~nm}$ thick layer of coating, that could be associated with the inclusion of antimicrobial agents (Jurgens \& Schwindt 2007). The $\mathrm{SiO}_{2}$ nanofilm has characteristics such as hydrophobia, oleophobia, a cationic nature, resistance to acids, excellent flexibility, antibacterial and antifungal properties, resistance to abrasion and corrosion, which inhibit the adhesion and proliferation of microorganisms (Jurgens \& Schwindt 2007, Wolinsky 2006). In this context, the $\mathrm{SiO}_{2}$ nanofilm has been suggested as an antimicrobial bioprotective coating for dental devices made of acrylic resin (Vilar 2014).

However, the silicon nanoparticles have great power of penetration into the systemic circulation (Napierska et al. 2010), and authors (Montanaro et al. 2005) have suggested studies to be conducted with the purpose of verifying possible biological damage, by means of cytotoxicity and biocompatibility tests at cellular level (Montanaro et al. 2005).

Considering the lack of in vivo biocompatibility studies of the $\mathrm{SiO}_{2}$ nanofilm (Napierska et al. 2010), the focus of this double-blind randomized study was to test the hypothesis that there would be no difference histological between the biocompatibility of conventional $\mathrm{SiO}_{2}$ (Montanaro et al. 2005) nanofilm-NP Liquid glass, and the enriched with antibacterial substances-Bacterlon, used as inhibitors of cellular growth on the acrylic surface.

\section{MATERIALS AND METHODS}

\section{Animal model and experimental groups}

For this study 60 adult male Wistar rats were used, weighing between 250-350g, belonging to the Vivarium of the Federal University of Campina Grande, UFCG. The animals were divided into 4 experimental groups ( $n=15$, per group): Group C (Control, Polyethylene), Group AR (Acrylic Resin), Group NP (Acrylic Resin coated with NP-Liquid Glass), Group BG (Acrylic Resin coated with Bacterlon Glass) (Table I). The animal experiment was approved by the Ethics Committee on Animal Research, CSTR/UFCG/ No.102016.

The acrylic resin samples were manipulated by the mass technique, in accordance with the manufacturer's instructions (Dos Santos et al. 2013), with the powder and liquid manipulated in the ratio of 3:1. The samples were fabricated by using a condensation silicon mold (Zhermack, Badia Polesine, RO, Italy), with an internal diameter of $6 \mathrm{~mm}$ by $\times 2 \mathrm{~mm}$ height.

Polymerization occurred within a resin polymerizer M-1000 (EDG, São Carlos, SP, Brazil), at a temperature of $20^{\circ} \mathrm{C}$, pressure of $25 \mathrm{psi}$ ( 1.75 $\left.\mathrm{kg} / \mathrm{cm}^{2}\right)$, for a period of 15 minutes, in accordance with the manufacturer's instructions. When excess material was present, it was progressively removed manually using abrasive papers with 150, 400, 600 and 800 grits. To obtain the desired dimensions, the specimens were measured with a precision pachymeter (123m-150; Starrett, SP, Brazil). All the samples were fabricated and polished by the same operator and stored in deionized water at 370 C (Millipore, Bedford, MA, USA) for 24 hours to allow the superficial residual monomers to be released (Rocha Filho et al. 2007). After this, both sides of the acrylic samples were previously sterilized with ultraviolet light (Labconco, Kansas City, MO, USA) for 30 minutes (Dos Santos et al. 2012).

Groups NP and BG were coated with $\mathrm{SiO}_{2}$ nanofilm NP-Liquid Glass and Bacterlon respectively. To ensure that all the sample walls would come into contact with the coating, each sample was placed in contact with $3 \mathrm{~mL}$ of the respective nanofilm. After 30 seconds, each sample was carefully removed and stored at ambient temperature for 24 hours to guarantee 
Table I. Silicon dioxide nanofilms tested in this study.

\begin{tabular}{|c|c|c|c|c|}
\hline Groups & Material & Composition & Manufacturer & Lot \\
\hline AR & Acrylic Resin & $\begin{array}{l}\text { Powder: Poly(methyl } \\
\text { methacrylate), } \\
\text { benzoyl- peroxide, } \\
\text { biocompatible } \\
\text { pigments } \\
\text { Liquid: Methyl } \\
\text { methacrylate } \\
\text { Monomer, Inhibitor }\end{array}$ & $\begin{array}{c}\text { OrtoCril, VIPI, } \\
\text { Pirassununga, SP, } \\
\text { Brazil }\end{array}$ & 1253 \\
\hline NP & NP-Liquid Glass & Silicon Dioxide & $\begin{array}{l}\text { Nanopool GmbH } \\
\text { (Schwalbach, } \\
\text { Germany) }\end{array}$ & A-LGPL/ 141009 \\
\hline BG & Bacterlon Glass & $\begin{array}{l}\text { Silicon Dioxide, } \\
\text { Chitosan, Trichloro- } \\
\text { 2'-hydroxydiphenyl } \\
\text { Ether (Triclosan) } \\
\text { and quaternary } \\
\text { ammonium salts }\end{array}$ & $\begin{array}{l}\text { Nanopool GmbH } \\
\text { (Schwalbach, } \\
\text { Germany) }\end{array}$ & A-BLPL/ 140603 \\
\hline
\end{tabular}

that the nanofilm had been correctly formed and dried. The samples were kept in a laminar flow chamber with the purpose of avoiding any type of contamination (Vilar 2014).

In this study, polyethylene discs with the same dimensions as those of the acrylic resin discs were used as controls of the trauma induced, and these were washed with deionized water and autoclaved at a temperature of $120^{\circ} \mathrm{C}$ for 20 minutes. After fabricating all the samples, the rats were anesthetized with intraperitoneal injection of sodium thiopental $(50 \mathrm{mg} / \mathrm{kg}$, Cristália, SP, Brazil). After this, trichotomy was performed with razor blades in the dorsal region of each animal $(4 \times 4 \mathrm{~cm})$.

For antisepsis of the operative field $4 \%$ chlorhexidine gluconate was used. On the midline, equidistant from the insertion of the animal's tale and head, two incisions approximately $8 \mathrm{~mm}$ long was made using a No.15 scalpel blade.

With the aid of a blunt tipped scissors, the subcutaneous tissue was laterally parted to promote a tunnel in the lateral direction, forming two surgical recesses, each approximately $18 \mathrm{~mm}$ deep. Each rat received two implants of the samples.

After the materials were implanted, the surgical recesses were sutured with a 4.0 suture thread (Ethicon, Jonhson\&Jonhson, SP, Brazil) and after the procedure, the animals received an injection of sodium dipyrone $(0.3 \mathrm{ml} / 100 \mathrm{~g}$, Sanofi-Aventis, Suzano, SP, Brazil).

All the procedures in this study were performed in compliance with the guidelines of the Canadian Council on Animal Care (1981). The animals were kept in individual cages and under adequate conditions with balanced rations and water ad libitum. After time intervals of 7, 15 and 30 days, the animals were anesthetized to obtain excisional biopsies of the implant area, including sufficient normal surrounding tissue, afterwards the rats were sacrificed by the cervical dislocation technique.

\section{Biocompatibility}

After fixation in $4 \%$ formaldehyde (Milony solution) for 24 hours, the samples were embedded in paraffin to obtain serial histologic cuts $6 \mu \mathrm{m}$ thick, and stained with hematoxylin and eosin. The inflammatory reaction induced 
by the samples was evaluated by using a light microscope (BX40; Olympus, Hamburg, Germany) at 100, 200 and 400x magnifications. Double blind examination was performed by two calibrated examiners (kappa=0.85).

The histological sections were made transversal-perpendicular direction to the operated area. For each sample of the study, five sections representative of the histological condition of the tissue adjacent to the implanted materials were analyzed. The cellular events with regard to the presence of inflammatory infiltrate, edema, necrosis, granulation tissue, mutinucleated giant cells, young fibroblasts and collagen, were awarded points according to the following scores: 1-absent (when absent in the tissue); 2-scarce (when scarcely present,or in very small groups), 3-moderate (when densely present,or in some groups) and 4-intense (when found in the entire field,or present in large numbers). The histological sections were randomly assessed at 5 different points of the tissue, adjacent to the specimen, when all five sections of the tissue showed the same histological condition. Scores: 1 , absent (5.00); 2, scarce (10.00); 3, moderate (15.00); and 4 , intense (20.00). These values represent the mean of scores of the sum of five representative histological sections of the tissue evaluated ( $n=5$, per group).

\section{Statistical analysis}

The data were tabulated and analyzed in the statistical program GraphPad Prism version 5.0 (San Diego, CA, USA). The statistical method was chosen based on the model of distribution and variance of data evaluated by the KolmogorovSmirnov and Levene tests, respectively. The results of the cellular events did not present normal distribution, therefore, they were submitted to the Kruskal-Wallis non parametric test, followed by the Dunn test to determine the differences among the groups $(P<.05)$.

\section{RESULTS}

In the initial period, intense inflammatory infiltrate was shown mainly in Groups BG and AR, with significant difference from Control Group in the time interval of 7days $(P=0.004)$. Intense inflammatory infiltrate was also demonstrated in Group BG in the time interval of 15 days, with significant difference from the Control Group ( $P=0.003$ ). No significant difference was demonstrated between the Groups evaluated in the time interval of 30 days $(P=0.454)$ (Table II) (Figure 1a-i).

Circulatory changes (edema) and tissue degeneration (necrosis) were significant, only in the time interval of 7 days, with significant difference between Group BG and Control Group $(P<0.05)$; and between Groups BG and NP for the presence of necrosis $(P=0.011)$. However, some necrotic events of little significance were still observed in Group BG in the time intervals of 15 days ( $P>0.05$ ) (Figure 1e). Granulation tissue was shown to be densely present in Groups AR and $\mathrm{BG}$ in the time interval of 7 days, with significant difference from the Control Group $(P=0.002)$, and subsequently there was a reduction in this cellular event, without statistical differences between the Groups in the time intervals of 15 $(P=0.237)$ and 30 days $(P=1.000)$.

There were more mutinucleated giant cells present in Group BG in the time intervals of 7 days $(P=0.010)$. Groups AR and BG demonstrated a similar condition for the presence of these cells in the time intervals of 15 days, with significant difference from the Control Group $(P=0.008)$ (Figure $1 d-e)$.

In the tissue repair events, Groups AR and $B G$ demonstrated the smallest quantity 
of young fibroblasts among the experimental Groups in the time intervals of 7 and 15 days, with significant difference only between the Control Group and Groups AR and BG ( $P=0.012)$ in the time intervals of 15 days. The quantity of collagen fibers increased over the course of the experimental time intervals evaluated (Figure 1gi), and there was significant difference between the Control Group and Groups AR and BG in the time interval of 7 days $(P=0.006)$, and between BG and Control Groups in the time intervals of 15 days $(P=0.010)$ (Table $I)$.

Table II. Mean of the scores attributed to the materials, after the time intervals of 7, 15 and 30 days, for the seven conditions evaluated ${ }^{\mathrm{a}}$.

\begin{tabular}{|c|c|c|c|c|c|c|}
\hline \multirow[t]{2}{*}{ Condition } & \multirow[t]{2}{*}{ Time, Days } & \multicolumn{4}{|c|}{ Groups } & \multirow[t]{2}{*}{$P^{*}$} \\
\hline & & $A R$ & $N P$ & $B G$ & C & \\
\hline \multirow[t]{3}{*}{ Inflammatory infiltrate } & 7 & $18.75^{\mathrm{A}}$ & $12.50^{\mathrm{AB}}$ & $20.00^{A}$ & $10.00^{B}$ & .004 \\
\hline & 15 & $15.00^{\mathrm{AB}}$ & $10.00^{A B}$ & $16.25^{\mathrm{A}}$ & $8.75^{\mathrm{B}}$ & .003 \\
\hline & 30 & 7.50 & 6.25 & 8.75 & 6.25 & .454 \\
\hline \multirow[t]{3}{*}{ Edema } & 7 & $8.75^{\mathrm{AB}}$ & $7.50^{\mathrm{AB}}$ & $10.00^{\mathrm{A}}$ & $5.00^{\mathrm{B}}$ & .039 \\
\hline & 15 & 6.25 & 5.00 & 6.25 & 5.00 & .543 \\
\hline & 30 & 5.00 & 5.00 & 5.00 & 5.00 & 1.000 \\
\hline \multirow[t]{3}{*}{ Necrosis } & 7 & $7.50^{\mathrm{AB}}$ & $5.00^{\mathrm{B}}$ & $10.00^{\mathrm{A}}$ & $5.00^{\mathrm{B}}$ & .011 \\
\hline & 15 & 5.00 & 5.00 & 7.50 & 5.00 & .092 \\
\hline & 30 & 5.00 & 5.00 & 5.00 & 5.00 & 1.000 \\
\hline \multirow[t]{3}{*}{ Granulation tissue } & 7 & $15.00^{\mathrm{A}}$ & $10.00^{\mathrm{AB}}$ & $15.00^{\mathrm{A}}$ & $8.75^{\mathrm{B}}$ & .002 \\
\hline & 15 & 10.00 & 8.75 & 10.00 & 7.50 & .237 \\
\hline & 30 & 5.00 & 5.00 & 5.00 & 5.00 & 1.000 \\
\hline \multirow[t]{3}{*}{ Mutinucleated giant cells } & 7 & $12.50^{\mathrm{AB}}$ & $7.50^{\mathrm{AB}}$ & $15.00^{\mathrm{A}}$ & $6.25^{\mathrm{B}}$ & .010 \\
\hline & 15 & $12.50^{\mathrm{A}}$ & $6.25^{\mathrm{AB}}$ & $12.50^{\mathrm{A}}$ & $5.00^{\mathrm{B}}$ & .008 \\
\hline & 30 & 7.50 & 5.00 & 8.75 & 5.00 & .061 \\
\hline \multirow[t]{3}{*}{ Young fibroblasts } & 7 & 7.50 & 10.00 & 7.50 & 12.50 & .071 \\
\hline & 15 & $11.25^{\mathrm{A}}$ & $15.00^{A B}$ & $11.25^{A}$ & $18.75^{B}$ & .012 \\
\hline & 30 & 15.00 & 13.75 & 16.25 & 12.50 & .237 \\
\hline \multirow[t]{3}{*}{ Collagen } & 7 & $5.00^{A}$ & $8.75^{\mathrm{AB}}$ & $5.00^{A}$ & $10.00^{B}$ & .006 \\
\hline & 15 & $12.50^{\mathrm{AB}}$ & $16.25^{\mathrm{AB}}$ & $10.00^{A}$ & $18.75^{B}$ & .010 \\
\hline & 30 & 16.25 & 18.75 & 16.25 & 20.00 & .092 \\
\hline
\end{tabular}

${ }^{a}$ For each sample of the study, five representative sections of the histological condition of the tissue were analyzed, when all five sections of the tissue showed the same histological condition. Scores: 1, absent (5.00); 2, scarce (10.00); 3, moderate (15.00); and 4, intense (20.00). *P indicates nonparametric Kruskal-Wallis test, followed by Dunn's multiple comparisons test. ${ }^{A \text { or } B}$ Means followed by the same single letter do not express statistically significant difference $(P>05) .{ }^{A B}$ Means followed by different letters express statistically significant difference $(P<.05)$. 

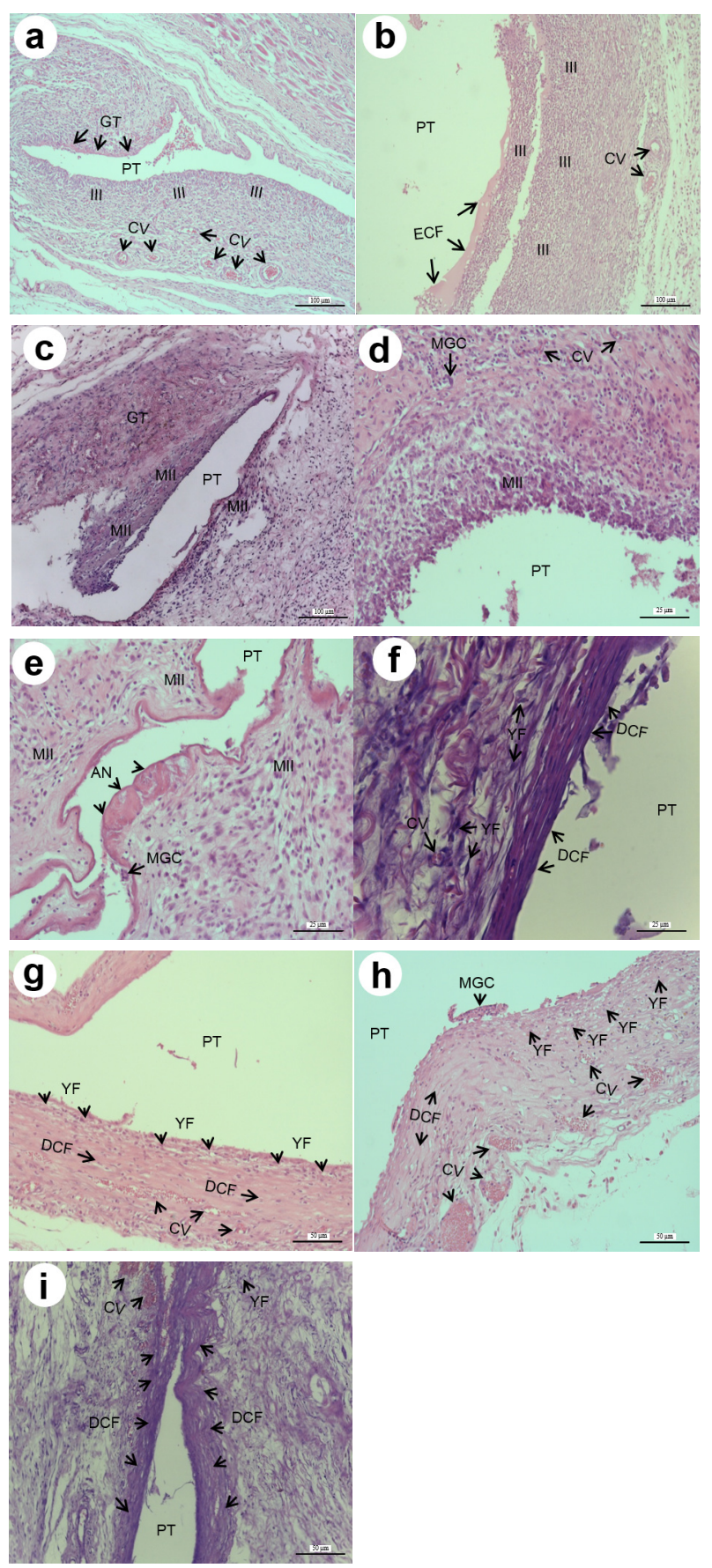

Figure 1. Photomicrographs of histological samples. a) 7 days after implantation, Group AR: intense inflammatory infiltrate (III), granulation tissue (GT) and congested blood vessels (CV) (HE, 100X magnification, scale:100 $\mu \mathrm{m})$. b) 7 days after implantation, Group BG: intense inflammatory infiltrate (III), congested blood vessels (CV) and presence of extracellular fluid (ECF) (HE, 100X magnification, scale:100 $\mu \mathrm{m}$ ). c) 7 days after implantation, Group C: cavity surrounded by moderate inflammatory infiltrate (MII) and granulation tissue reaction (GT) (HE, 100X magnification, scale:100 $\mu \mathrm{m})$. d) 15 days after implantation, Group AR: presence of moderate inflammatory infiltrate (MII) adjacent to the cavity, congested vessels (CV) and presence of multinucleated giant cells (MGC) (HE, 400X magnification, scale:25 $\mu \mathrm{m}$ ). e) 15 days after implantation, Group BG; presence of moderate inflammatory infiltrate (MII), small areas of necrosis (AN) adjacent to the cavity, and presence of multinucleated giant cells (MGC) (HE, 400X magnification, scale:25 $\mu \mathrm{m}$ ). f) 15 days after implantation, Group C; slight mononunclear inflammatory infiltrate, presence of young ovoid and fusiform fibroblasts (YF), congested blood vessels (CV) and deposition of collagen fibers (DCF), (HE, 400X magnification, scale:25 $\mu \mathrm{m}$ ). g) 30 days after implantation, Group AR; cavity surrounded by thick band with deposition of collagen fibers (DCF), young ovoid and fusiform fibroblasts (YF), presence of congested blood vessels (CV) and slight chronic inflammatory infiltrate (HE, 200X magnification, scale: $50 \mu \mathrm{m})$. h) 30 days after implantation, Group BG; cavity surrounded by collagenization band with deposition of collagen fibers (DCF) sometimes disposed in parallel bands and sometimes in varied bands, young ovoid and fusiform fibroblasts (YF), presence of slight chronic inflammatory infiltrate, congested blood vessels (CV) and multinucleated giant cells (MGC) (HE, 200X magnification, scale:50 $\mu \mathrm{m}$ ). i) 30 days after implantation, Group C; deposition of collagen fibers (DCF) disposed in parallel bands involving the area of the cavity, young fibroblasts (YF) and presence of blood vessels (CV), (HE, 200X magnification, scale:50 $\mu \mathrm{m}$ ). Area of polyethylene tube implant (PT). 


\section{DISCUSSION}

Microorganisms, such as the acidogenic (Streptococcus mutans, Streptococcus gordinii) and proteolytic bacteria (Porphyronomas gingivalis, Prevotella intermedia) and fungi, such as Candida albicans, are frequently found in the oral cavity (Piovano 1999). Thus it is common to find large quantities of biofilm on dental and orthodontic appliances, leading to inflammation, stomatitis and erythema in the mucosa (Lacerda-Santos et al. 2014, Mesquita et al. 2017, Uzunoglu et al. 2014). To prevent these sources of harm, it is important to implement control and biosafety measures whose efficiency has been proved.

In this context, $\mathrm{SiO}_{2}$-based nanofilm has appeared as an alternative for providing complementary biosafety care (Vilar 2014). Silica nanoparticles, the main component of nanofilm, have demonstrated good results both in vitro, and in vivo (Fruijtier-Polloth 2012), and more serious inflammations have been observed only on exposure to high levels of inhalation or injection of nanoparticles (Johnston et al. 2000, Sayes et al. 2010).

In the present study, the inflammatory infiltrate found was shown to be significantly greater in the Acrylic Resin (AR) and Bacterlon Glass (BG) Groups in the time interval of 7 days. In the period of 15 days, significant infiltrate continued to persist in Group BG. These results suggested a greater capacity for aggression against the Bacterlon tissues, due to the presence/or concentration of the antimicrobial substances such as chitosan, triclosan and quaternary ammonia salts present in this nanofilm. Studies (Thanou et al. 2001, Wedmore et al. 2006) have reported that chitosan is considered compatible with the tissues, however, changes made in this drug to adjust formulations may have a direct influence on its capacity to cause tissue damage and influence inflammatory events (Kean \& Thanou 2010). In addition to this, authors (Lyman \& Furia 1969) have demonstrated the toxicity of triclosan and its influence on the cellular events in epithelial cells of human gingival cells (Zuckerbraun et al. 1998). In conjunction, quaternary ammonia has been shown to be cytotoxic to the mitochondria of epithelial cells (Inacio et al. 2013) and to have the potential to increase cell damage.

There was significant presence of edema and necrosis only in Group BG in the time interval of 7 days, which demonstrated a capacity for initial aggression, but that was not persistent in the subsequent time intervals. Although irreversible cell damage and subsequent cell death in the short term have been found, the histological evaluations suggested a low capacity of Bacterlon to lead to significant damage in the long term. On the other hand, granulation tissue was shown to be densely present in Groups AR and $B G$ in the time interval of 7 days, a condition that did not persist significantly in the following time intervals.

Multinucleated giant cells were shown to be more present in Group BG in the time interval of 7 days; their significant presence persisted in Group BG, and was also demonstrated in Group AR in the time interval of 15 days, which corresponded to the organism's response to phagocyting the foreign body through these cells (Lacerda-Santos et al. 2016). In Group BG, the presence/or concentration of antimicrobial substances present in this material could be related to the increase in these cells; for Group AR, the presence of multinucleated giant cells suggested that this could be linked to the toxicity of the acrylic resin due to the presence of residual monomer released after its polymerization, with the degradation of its components over the course of time (Ivković et al. 2013). 
In tissue repair, there was growing presence of young fibroblasts that was not significant among the materials, except for Groups AR and BG that demonstrated a lower number of young fibroblasts in the time interval of 15 days. The presence of collagen was shown to be lower in Groups AR and BG in the time interval of 7 days; this suggested that the tissue toxicity of Groups AR and BG had the capacity to interfere in the production of collagen and non-collagen protein, as has been seen in other substances (Ivković et al. 2013).

The tissue toxicity in Group AR was directly related to the release of monomer residues (Dos Santos et al. 2013, Ivković et al. 2013), and Bacterlon with the presence of its antimicrobial agents, which corroborated the findings of a study (Vilar 2014) that demonstrated its cellular toxicity in vitro associated with its potential to inhibit the growth of bacteria of the S.mutans and S.aureus types, and fungi of the C. albicans type (Vilar 2014).

Studies (Thanou et al. 2001, Wedmore et al. 2006) have reported that the changes made in the density of the molecular load of chitosan and its route of administration are directly related to its toxicity (Thanou et al. 2001, Wedmore et al. 2006) and the type of cell affected (Kean \& Thanou 2010). Triclosan (Zuckerbraun et al. 1998), in tests for verifying cellular apoptosis, has also presented considerable cellular damage, particularly when the time of exposure to it and its concentration were increased (Jirasripongpun et al. 2008). Added to these factors the quaternary ammonia salts have demonstrated cytotoxicity in epithelial cells (Inacio et al. 2013), although other authors (Grabińska-Sota 2011) have found no strong evidence of risks to human health. In conjunction, these agents have been suggested to have significant potential for increasing initial cellular damage and to slow down the time of response for tissue repair.
The $\mathrm{SiO}_{2}$ nanofilm without the presence of antimicrobial agent, NP-Liquid Glass, demonstrated significantly promising results in comparison with Bacterlon, with a higher level of tissue biocompatibility for all the cellular events evaluated, which corroborated the finding of studies (Vilar 2014) that evaluated the in vitro cellular cytotoxicity of these nanofilms in L929 fibroblasts; moreover, NP-Liquid Glass demonstrated the potential to inhibit the growth of bacteria of the S. aureus type (Vilar 2014). Authors (DeLoid et al. 2017, Landgraf et al. 2017) have demonstrated a low cytotoxicity profile of $\mathrm{SiO}_{2}$ nanoparticles, however, they have pointed out that variations in the preparation/ formulation of the nanoparticles may have a significant influence on the results of cellular tests (Landgraf et al. 2017), so that further analyses and standardizations are necessary (DeLoid et al. 2017).

The biocompatibility presented by NPLiquid Glass demonstrated clinical applicability promising as a bioprotective coating with low deleterious risk to the individual. However, it is suggested the use of Bacterlon only in small acrylic devices for individuals who are not allergic to the antimicrobial substances present in this nanofilm. The elevated cytotoxicity of Bacterlon has been suggested to be caused by the high antibacterial power of its components, however, when this toxicity has ceased, the material could continue to be an excellent option for coating surfaces that come into contact with live beings (Vilar 2014). For the purpose of confirming this hypothesis, long-term studies about cytotoxicity/biocompatibility are necessary to evaluate until when the material generates cellular/tissue damage, and up to what point its antimicrobial capacity remains active. 


\section{CONCLUSIONS}

The hypothesis was rejected. Bacterlon demonstrated the lowest level, and NP-Liquid Glass the highest level of tissue compatibility, and best cell repair. The coating with NP-Liquid Glass was demonstrated to be highly promising for use in clinical practice.

\section{REFERENCES}

COMPAGNONI MA, PERO AC, RAMOS SM, MARRA J, PALEARI AG \& RODRIGUEZ LS. 2014. Antimicrobial activity and surface properties of an acrylic resin containing a biocide polymer. Gerodontology 31: 220-226.

DELOID GM, COHEN JM, PYRGIOTAKIS G \& DEMOKRITOU P. 2017. Preparation, characterization, and in vitro dosimetry of dispersed, engineered nanomaterials. Nat Protoc 12: 355-371.

DOS SANTOS RL, PITHON MM, CARVALHO FG, RAMOS AA \& ROMANOS MT. 2013. Mechanical and biological properties of acrylic resins manipulated and polished by different methods. Braz Dent J 24: 492-497.

DOS SANTOS RL, PITHON MM, MARTINS FO, ROMANOS MT \& RUELLAS AC. 2012. Evaluation of cytotoxicity and degree of conversion of glass ionomer cements reinforced with resin. Eur J Orthod 34: 362-366.

FRUIJTIER-POLLOTH C. 2012. The toxicological mode of action and the safety of synthetic amorphous silica-a nanostructured material. Toxicology 294: 61-79.

GRABIŃSKA-SOTA E. 2011. Genotoxicity and biodegradation of quaternary ammonium salts in aquatic environments. J Hazard Mater 195: 182-187.

INACIO AS, COSTA GN, DOMINGUES NS, SANTOS MS, MORENO AJ, VAZ WL \& VIEIRA OV. 2013. Mitochondrial dysfunction is the focus of quaternary ammonium surfactant toxicity to mammalian epithelial cells. Antimicrob Agents Chemother 57: 2631-2639.

IVKOVIĆ N, BOŽOVIĆ D, RISTIĆ S, MIRJANIĆ V \& JANKOVIĆ O. 2013. The residual monomer in dental acrylic resin and its adverse effects. Contemp Mater 1: 84-91.

JIRASRIPONGPUN K, WONGARETHORNKUL T \& MULLIGANAVIN S. 2008. Risk assessment of triclosan using animal cell lines. Kasetsart J 42: 353-359.

JOHNSTON CJ, DRISCOLL KE, FINKELSTEIN JN, BAGGS R, O'REILLY MA, CARTER J \& OBERDORSTER G. 2000. Pulmonary chemokine and mutagenic responses in rats after subchronic inhalation of amorphous and crystalline silica. Toxicol Sci 56: 405-413.

JURGENS R \& SCHWINDT S. 2007. Anitbakterielle coating composition based on a silica-generating agent, a set of applications, a nanoscale coating the preparation of the coating, further processing of the coating as well as their use. Google Patents.

KEAN T \& THANOU M. 2010. Biodegradation, biodistribution and toxicity of chitosan. Adv Drug Deliv Rev 62: 3-11.

LACERDA-SANTOS R, DE FARIAS MI, DE CARVALHO FG, PITHON MM, ALVES PM, TANAKA OM \& GUENES GM. 2014. In ViVO biocompatibility versus degree of conversion of resinreinforced cements in different time periods. Microsc Res Tech 77: 335-340.

LACERDA-SANTOS R, DE MENESES IH, SAMPAIO GA, PITHON MM \& ALVES PM. 2016. Effect of degree of conversion on in vivo biocompatibility of flowable resin used for bioprotection of mini-implants. Angle Orthod 86: 157-163.

LANDGRAF L, NORDMEYER D, SCHMIEL P, GAO Q, RITZ S \& HILGER I. 2017. Validation of weak biological effects by round robin experiments: cytotoxicity/biocompatibility of SiO2 and polymer nanoparticles in HepG2 cells. Sci Rep 7: 34-41.

LYMAN FL \& FURIA T. 1969. Toxicology of 2, 4, 4'-trichloro-2'hydroxy-diphenyl ether. IMS Ind Med Surg 38: 64-71.

MESQUITA JA, LACERDA-SANTOS R, GODOY GP, NONAKA CFW \& ALVES PM. 2017. Morphological and immunohistochemical analysis of the biocompatibility of resin-modified cements. Microsc Res Tech 80: 504-510.

MONTANARO L, CERVELLATI M, CAMPOCCIA D, PRATI C, BRESCHI L \& ARCIOLA CR. 2005. No genotoxicity of a new nickel-free stainless steel. Int J Artif Organs 28: 58-65.

MUTTERS NT, HAGELE U, HAGENFELD D, HELLWIG E \& FRANK U. 2014. Compliance with infection control practices in an university hospital dental clinic. GMS Hyg Infect Control 9: 3-18.

NAPIERSKA D, THOMASSEN LC, LISON D, MARTENS JA \& HOET PH. 2010. The nanosilica hazard: another variable entity. Part Fibre Toxicol 7: 39.

OLSEN I \& BIRKELAND JM. 1977. Denture stomatitis-yeast occurrence and the $\mathrm{pH}$ of saliva and denture plaque. Scand J Dent Res 85: 130-134.

PIOVANO S. 1999. Bacteriology of most frequent oral anaerobic infections. Anaerobe 5: 221-227.

ROCHA FILHO R, PAULA LV, COSTA VC \& SERAIDARIAN PI. 2007. Evaluation of residual monomer in autopolymerizing 
acrylic resins: spectroscopy analysis. Dental Press J Orthod 12: 96-104.

SAYES CM, REED KL, GLOVER KP, SWAIN KA, OSTRAAT ML, DONNER EM \& WARHEIT DB. 2010. Changing the dose metric for inhalation toxicity studies: short-term study in rats with engineered aerosolized amorphous silica nanoparticles. Inhal Toxicol 22: 348-354.

SESMA N, LAGANA DC, MORIMOTO S \& GIL C. 2005. Effect of denture surface glazing on denture plaque formation. Braz Dent J 16: 129-134.

THANOU M, VERHOEF JC \& JUNGINGER HE. 2001. Oral drug absorption enhancement by chitosan and its derivatives. Adv Drug Deliv Rev 52: 117-126.

UZUNOGLU E, YILDIRIM BICER AZ, DOLAPCI I \& DOGAN A. 2014. Biofilm-forming ability and adherence to poly-(methylmethacrylate) acrylic resin materials of oral Candida albicans strains isolated from HIV positive subjects. J Adv Prosthodont 6: 30-34.

VILAR RV. 2014. Silicon dioxide nanofilm as inhibitor of microbial growth on plastic surface. (Dissertation, Master in Orthodontics), Federal University of Rio de Janeiro, UFRJ. (Unpublished).

WEDMORE I, MCMANUS JG, PUSATERI AE \& HOLCOMB JB. 2006. A special report on the chitosan-based hemostatic dressing: experience in current combat operations. J Trauma 60: 655-658.

WOLINSKY H. 2006. Nanoregulation: a recent scare involving nanotech products reveals that the technology is not yet properly regulated. EMBO Rep 7: 858-861.

ZUCKERBRAUN HL, BABICH H, MAY R \& SINENSKY MC. 1998. Triclosan: cytotoxicity, mode of action, and induction of apoptosis in human gingival cells in vitro. Eur J Oral Sci 106: 628-636.

\section{How to cite}

LACERDA-SANTOS R, LIMA ABL, PENHA ES, SANTOS A, CARVALHO FG, PITHON MM \& DANTAS AFM. 2020. In vivo biocompatibility of silicon dioxide nanofilm used as antimicrobial agent on acrylic surface. An Acad Bras Cienc 92: e20181120. DOI 10.1590/0001-3765202020181120.

Manuscript received on October 23, 2018; accepted

for publication on October 11, 2019

\section{ROGÉRIO LACERDA-SANTOS 1}

https://orcid.org/0000-0002-6213-9206

\section{ANTONIA BÁRBARA L. LIMA ${ }^{2}$}

https://orcid.org/0000-0002-0591-4229

\section{ELIZANDRA S. DA PENHA ${ }^{2}$}

https://orcid.org/0000-0001-6264-5232

\section{ANTONIELSON DOS SANTOS ${ }^{3}$}

https://orcid.org/0000-0002-5686-8621

FABÍOLA G.CARVALHO

https://orcid.org/0000-0003-2510-1329

MATHEUS M. PITHON ${ }^{4}$

https://orcid.org/0000-0002-8418-4139

\section{ANTÔNIO FLÁVIO M. DANTAS 3}

https://orcid.org/0000-0002-6123-2273

${ }^{1}$ Universidade Federal de Juiz de For a/UFJF, Instituto de Ciências da Vida, Faculdade de Odontologia, Departamento de Ortodontia e Odontopediatria, Av. Doutor Raimundo Monteiro Rezende, no 330, Centro, 35010-177 Governador Valadares, MG, Brazil

${ }^{2}$ Universidade Federal de Campina Grande/UFCG, Faculdade de Odontologia, Departamento de Ortodontia e Odontopediatria, Av. dos Universitários, s/n, Rodovia Patos/ Teixeira, Km 1, Santa Cecília, 58708-110 Patos, PB, Brazil

${ }^{3}$ Universidade Federal de Campina Grande/UFCG, Faculdade de Medicina Veterinária, Departamento de Patologia, Av. dos Universitários, s/n, Rodovia Patos/ Teixeira, Km 1, Santa Cecília, 58708-110 Patos, PB, Brazil ${ }^{4}$ Universidade Estadual do Sudoeste da Bahia/ UESB, Faculdade de Odontologia, Departamento de Ortodontia e Odontopediatria, Av. José Moreira Sobrinho, s/n, Jequiezinho, 45205-490 Jequié, BA, Brazil

Correspondence to: Rogério Lacerda-Santos

E-mail: lacerdaorto@hotmail.com, lacerdaorto@gmail.com

\section{Author contributions}

RLS participated in the conception of the study and data interpretation, revised the manuscript, and coordinated the research project. ABLL participated in the conception of the study design, acquired the data, performed the laboratorial processes, and drafted the manuscript. ESP revised the manuscript critically for important intellectual content. AS performed laboratorial processes. FGC revised the manuscript critically for important intellectual content. MMP participated in the data acquisition, data analysis and interpretation. AFMD performed laboratorial processes and participated in the data acquisition. All authors read and approved the final manuscript.

\section{(c) BY}

